\title{
Families Benefiting from Social Assistance in Poland - Strategies and Barriers to Poverty Reduction
}

\author{
By Magdalena Pokrzywa ${ }^{1}$
}

\begin{abstract}
The article aims to characterize the remedial strategies undertaken by Polish families using social assistance to minimize material deprivation and the main barriers to empowerment of such families. The source of data are the results obtained as part of the author's own research, which were conducted with social workers in Poland and had quantitative (500 CATI) and qualitative (90 IDI) nature. In families living in difficult economic conditions, both active and passive activities are used to obtain the missing funds. Active strategies include taking up a job (permanent, additional or occasional, legal or in the so-called 'gray area'), selling or exchanging skills, time and goods, borrowing money, or applying for support to institutions (which is mainly a female domain). Women also implement many passive strategies that involve saving or reducing consumption by, for example, preparing dishes from cheap products, shopping in places with the lowest prices, buying second-hand items, etc. The main barriers to minimizing the poverty of families benefiting from social assistance in Poland are related to their life attitude and the gender of its members. Remedial strategies for difficult financial situations undertaken by poor families benefiting from social assistance vary depending on the type of family, problem(s) they experience and the resources they have. The strategies undertaken also depend on the gender of family members experiencing poverty.
\end{abstract}

Keywords: poverty, family, social assistance, social worker, gender

\section{Introduction}

The availability of goods and services considered essential or necessary is not evenly distributed in a society. Some households have almost unlimited access to them, others have limited but sufficient access to maintain the health and social functioning of all members at a satisfactory level, but there are also those whose access to these goods and services is so limited that it becomes a problem or even a threat to their existence (Szarfenberg, 2009). In situations where individuals and families are unable to deal with the problem or many problems that threaten their proper functioning on their own, they can turn to social welfare institutions for support. Social assistance is an institution of state social policy aimed at enabling individuals and families to overcome difficult life situations which they are unable to overcome by using their own entitlements, resources and possibilities (Ustawa o pomocy społecznej, 2004). The essence of social assistance is to lead, as far as possible, to the independence of persons and families in life and their integration with the community. The way of support, its type, form and size should be appropriate to the circumstances justifying the aid and should serve to strengthen the family (Zasada-Chorab, 2012).

Within the meaning of the Act on Social Assistance in Poland, families are related or 
unrelated persons in a factual relationship, living together and managing. Social assistance consists in particular of granting and paying benefits, social work, providing shelter and food and necessary clothing, paying insurance premiums, providing in-kind assistance, specialist advice, crisis intervention, providing care services (Ustawa o pomocy społecznej, 2004). The vast majority of social assistance beneficiaries benefit above all from various forms of material support aimed at satisfying current consumption needs in connection with experienced material deprivation (Zalewski, 2005). Social welfare institutions pursue the state's redistribution policy in the most direct form, having at their disposal financial benefits, while social workers are their representatives (Pilch, 2005).

Social assistance and social work are addressed to people and families at risk of poverty and social exclusion, but entitlement to social assistance benefits is linked to two criteria which must be met simultaneously. First, it is a criterion of insufficient financial resources. The right to cash benefits is granted to persons and families whose financial resources do not exceed the income criteria, which constitute the so-called threshold for entering the social assistance system and are at the same time the formal, official poverty line (Golinowska, Broda-Wysocki, 2005). The second criterion was listed in the Act on Social Assistance and specifies additional circumstances which, apart from low income (statutory poverty), indicate those entitled to benefit from institutional support, e.g. longterm or severe illness; homelessness; unemployment; disability; family violence; helplessness in caring and educational matters and running a household; the need to protect motherhood or many children; alcoholism or drug addiction; etc. (Ustawa o pomocy społecznej, 2004).

The article aims to characterize the remedial strategies undertaken by Polish families using social assistance to minimize material deprivation and the main barriers to empowerment of such families. The source of data are the results obtained as part of the author's own research, which were conducted with social workers in Poland and had quantitative (500 CATI) and qualitative (90 IDI) nature.

\section{Experience of Poverty and Remedial Strategies to Minimize It}

According to data from the Central Statistical Office in Poland, in 2019 about $11 \%$ of people in households experienced statutory poverty. Poverty was faced mainly by persons and families living on so-called non-earned sources of income (except for pensions), families with three or more dependent children, children aged 0-17 years, households with a head of family having at most lower secondary education, as well as rural families and families with people with disabilities (GUS, 2019a). The statutory poverty line indicates the category of persons who, in accordance with the applicable regulations, are entitled to apply for a social assistance cash benefit. Persons and/or families whose income does not exceed the so-called social intervention threshold may apply for support to a social assistance institution in a situation of poverty in order to obtain financial benefits. Social assistance implemented in 2018 on the basis of the Act on Social Assistance was addressed to 896.2 thousand households and covered 1970.4 thousand beneficiaries, i.e. 5.1\% of Polish population. The share of households of beneficiaries of social assistance in the total number of households in Poland in 2018 was 
$6.3 \%$. In the category of social welfare beneficiaries, members of multi-person households, mainly single-family households with dependent children (about 75\%), dominate. More than half of social assistance beneficiaries live in rural areas (GUS, 2019b).

Poor families who benefit from social assistance often take various additional measures to improve or not to make their situation worse. These strategies for maximizing income and minimizing needs and spending by the poor pay attention to their efficiency and activity. They break to some extent the thinking of the whole category of the poor as helpless, claimant and inactive (Janocha, Olesińska, 2019). In the literature on the subject we can see various classifications of actions taken by the poor, aimed at an immediate improvement of the difficult situation of the household or constituting a long-term process of getting out of poverty. Members of poor families undertake various types of strategies which can be described as a series of choices limited to a greater or lesser extent by macroeconomic circumstances, the social, cultural and ideological context and expectations, as well as by access to resources (Racodi, 2002). These activities are strongly influenced by external factors. As Tyszka (2002) proves, processes taking place in the family are stimulated not only by interactions taking place within it. The features of the family and the course of phenomena within it also have significant conditions in the external, non-family social world, in particular systems, social structures located outside the family - microstructure, mesostructure, macrostructure and global society (Polish society). The interactions taking place between the family and particular circles of the external social world are mutual.

Actions aimed at improving the material situation of the family are therefore also strongly conditioned by the socio-economic situation surrounding the family, local environment resources, local and national labour market, social infrastructure, etc. Tarkowska (2004) points out that families living in difficult economic conditions, on the one hand, applies active measures in order to obtain additional, missing funds, on the other hand, there are many so-called passive ways of adapting to the conditions of poverty, consisting in saving, reducing or minimizing needs and ways of satisfying them. One of the many classifications of strategies for dealing with the situation of poverty is the division indicating such actions as: multiplying income, minimizing expenses and managing stress (Lister, 2007). Low income requires a variety of measures to minimize the shortfall in the household budget. The financial difficulties of families result in their varied reactions: offensive, action-oriented, aimed at actively seeking additional sources of income, or more defensive, aimed at seeking savings by reducing needs (Janocha, Olesińska, 2019). Active income maximization strategies include undertaking (often additional) work in the country and/or abroad, also in the so-called grey economy and overtime work, as well as preparing for the sale of various types of own products. Often a characteristic feature of poor families is the inclusion of children and young people, who often do seasonal work during the holidays (e.g. picking fruit, watching over children's neighbours) (Tarkowska, 2015). Austerity strategies generally involve a significant reduction or complete abandonment of even the most urgent expenditure on food, clothes, medicines, housing, doctor's appointments, heating, education, social life, etc. Another way of saving is shopping in discount stores during promotions, bazaars and second-hand clothing stores (on the day of the highest discount). Often purchased 
products are of lower quality. Poor families apply restrictions on the use of running water, electricity, or in the winter season do not heat all the rooms in the house, only those most frequently used (Janocha, Olesińska, 2019).

Strategies to deal with family poverty also have a gender dimension. Sassen (2000) draws attention to the phenomenon of feminization of survival, which she defines as an increase in the dependence of households in solving poverty problems on women's caring work and incomes transferred by women in the transnational formal and informal work and money circulation. In poor families it is women who take responsibility for budget planning. They lavish between needs and opportunities, becoming "poverty managers". Planning and combining contacts with support institutions requires a lot of time and effort. This resourcefulness of women in situations of poverty is burdened with a heavy psychological burden, which they bear when confronted with a sense of discouragement and helplessness (Lister, 2007).

\section{Methodology}

The article is based on the author's own research, which was of quantitative and qualitative nature. By undertaking qualitative research the researcher tries to understand the behaviours, institutions and organisations by getting to know the people involved, their values, emotions, attitudes, beliefs and opinions (Frankfort-Nachmias and Nachmias, 2001). In the research process, the technique of individual in-depth interview (IDI) was used, which is based on the interaction between the researcher and the interviewee, during which the topics identified for the research are addressed (Babbie, 2008). This technique allows to try to understand the world from the point of view of the research subjects, by developing the meaning of people's experiences in order to discover the world they are experiencing (Kvale, 2004). In qualitative research, the voice of the subjects, i.e. social actors, should be strongly emphasized in the text by quoting statements that make the analysis scientifically and realistically valid and present the area under study reliably (Kostera, Kociatkiewicz, 2014). The quantitative measurement was carried out by means of computer-assisted telephone interviewing (CATI). The CATI research is based on the scheme of an individual questionnaire interview carried out over the phone. In CATI research the interviews are usually shorter than in field research. Their length does not exceed 20-25 minutes (Sztabiński, Sawiński, Sztabiński, 2005).

A qualitative study was conducted with 90 social workers. While, 500 social workers took part in the CATI technique. Both in the qualitative and quantitative research, the surveyed employees represented social welfare centres located in Poland in large, large, medium and small towns and rural areas. It was decided to choose this professional category, because social workers in their daily work cooperate with families who are in a problematic situation and are not able to overcome it on their own. Social workers are observers of family life, professionally providing institutional support, among others, to families experiencing poverty. Social welfare centres in Poland are organizational units carrying out social assistance tasks in communes. There are about 2.5 thousand social welfare centres in Poland, with 57,824 employees, including 19,596 as social worker (MRPiPS, 2019). 


\section{Results}

\subsection{Remedial strategies undertaken by family members benefiting from social assistance in the opinion of the respondents}

In the opinion of the social workers, active strategies manifested by representatives of families benefiting from social assistance include first of all taking up employment (permanent, additional or casual). Due to the significant burden of family and household duties and the still functioning social connection of women with the private sphere, professional work is usually undertaken by men (fathers, husbands/partners). This work is very often carried out without an official contract, i.e. in the so-called grey market, which according to some social workers results from the conditions of local labour markets (few job offers, especially in rural areas distant from urban centres), the attitude of some employers (who prefer to employ workers illegally) and the quality of human capital of social assistance clients (low level of education and little professional experience). As one of the social workers indicates: These people often have a low level of education - basic, even if they have a job, they do not have professional experience, documented as such. Because if they take up a job, it is usually in so-called: grey market. This labour market is also still poor (...) Often employers do not want to bire on a contract, only either on a contract of mandate or in the grey market (Social worker, 37 years old, small town).

Other social workers, on the other hand, stressed that working in the so-called grey market and obtaining undocumented income is aimed at cheating the social assistance system in order to obtain benefits which, if employment is legalized, families might no longer be entitled to: It is often the case that income is hidden. The partner, whether a cohabiting partner or spouse, works in the black market and is registered with the employment office as an unemployed person. He or she receives an income that is hidden, so families get caught up in the criteria to apply for social assistance. They take up jobs in the black labour somewhere, in the meantime being registered in the labour office and being unemployed, they meet the conditions for financial aid, so families get it and that's how it works (Social worker, 56 years old, big city). Social workers pointed out that they do not have legal tools to verify such situations and it is difficult for them to prove that a given person or family using the social assistance system obtains unauthorized support. The use of the system by beneficiaries in this way is aimed at multiplying the family income and is not perceived by them as something negative, but even creative. Such a way of obtaining means of subsistence by families is illegal and socially unaccepted.

The phenomenon of material deprivation is closely linked to the problem of employment. Work is a source of income which to a large extent enables the needs of individuals and families to be met. However, the contemporary changes on the labour market (especially the instability of employment, structural shortage of jobs, low level of income obtained from work, inter alia, due to the so-called junk contracts, etc.) cause that apart from the hitherto disadvantaged categories (unemployed, disabled, dysfunctional people), so called the working poor are also at risk of deprivation of needs. Apart from the permanence of employment, the level of wages, including the minimum wage, is crucial. In general, due to the lack of adequate vocational training, the employment of the working poor is located in the least profitable sectors or occupations (Firlit-Fesnak, 2015). Among the beneficiaries of social assistance there are also families 
(especially those with many children), in which despite the legal work of one (or two) of the parents, the income obtained is insufficient to ensure a life at a level that allows them to meet the living and social needs of family members.

The active nature of remedial strategies is also the sale or exchange of skills, time and goods, prepared especially with a view to monetizing them, borrowing money from family, friends or institutions. Social workers also point out that such an active strategy may also be considered to be the application of family representatives for support to social welfare institutions. The respondents indicate that such action is usually taken by women, representatives of full or monoparent families. It is estimated that over $80 \%$ of people applying for support for their own family from social assistance are women, who usually represent a full family (GUS, 2019a). In the opinion of social workers, such a situation is connected, on the one hand, with a higher risk of poverty for women than for men (the phenomenon of the so-called feminization of poverty) and, on the other hand, results from the roles assigned to women and men by society. These roles constitute a socio-cultural range of individual behaviour, which expresses expectations for women and men and their place in society (Pankowska, 2005). The traditional vision of a man's role places him in the public sphere and makes him responsible for earning an income through gainful employment. On the other hand, the woman is still assigned to the private sphere, making her responsible for fulfilling domestic and caring duties (Titkow, Duch-Krzystoszek, Budrowska, 2004). Social workers pointed out that women undertake contacts with social welfare centre representing the family, because when partners/husbands work (even on a casual basis), it is easier for women (usually staying in the household with children) to go to the centre during its working hours. On the other hand, they stressed that there is a large category of families benefiting from social assistance in which a woman is responsible for providing support from institutions due to men's reluctance to undertake such activities: It can be said that from dealing with such unpleasant things - that's how some clients see it, that they have to come and tell their whole life story to get anything - it's women who are delegated. Sometimes it is difficult to take a statement from a man because be thinks it is not his business. It is usually the woman who, in situations when a family is suddenly in a difficult financial situation, takes up such a struggle and tries to secure the needs of the family (...) Looking at these cases, which I have conducted within the framework of financial aid, these women always said that they have no other choice but to go to the welfare centre to secure the needs of their children. When her husband was supposed to meet with me, it was usually such a difficulty and such a reluctance, because why would he meet a social worker when his wife wants help? He didn't understand that his wife was trying to get help for his family, so for him too (Social worker, 42 years old, big city).

Social workers pointed to the functioning of the so-called home matriarchy (Walczewska, 1999) or menagerie matriarchy (Titkow, 1996) in poor families benefiting from social assistance, which manifested itself in women taking control and managing family matters: Usually in these families, however, it is the women who are the heads of the family and take care of everything. Husbands don't usually work. Then comes the mother as the head of the family, who takes care of everything, and like a lioness wants to win as much as possible here (Social worker, 36 years old, big city). The role of women as "poverty managers" (Lister, 2007) is paid for by a lot of sacrifices, time, effort and fatigue. Women also pursue many passive strategies that involve saving or reducing consumption by, for example, preparing food from cheap 
products, shopping at the lowest prices, buying used goods, etc. (Tarkowska, 2015). Men prefer to avoid such activities for reasons of convenience, pride, or preference for poverty reduction through work: $A$ woman will go everywhere, and a man will not even go, so to speak, to a second-hand clothing store. And a woman will go everywhere, to every institution, and a man is so embarrassed, so proud (Social worker, 37 years old, rural area).

According to social workers, women generally represent the whole family when seeking support and see the complexity of family problems - e.g. upbringing and schooling problems, partner/spouse addiction, etc. Women also take more active steps to support the family and get out of a difficult financial situation, are more likely to be discouraged and are interested in different types of support for the whole family. Men, on the other hand, focus to a large extent on their own problem, e.g. unemployment, and are generally only interested in financial support: Women are also more interested in other support. Financial support is known to be important, but also this other kind of support such as social work, contact with a psychologist, or some kind of counselling. Men, on the other hand, are a bit worse. For example, we organized courses for people, so definitely more women were willing to cooperate, to participate in such a course, training. Women are more willing to cooperate. They are more active than men, that's for sure. You can see as I say after participants in training or courses. We have had a course of welders and, surprisingly, we have had women on welder's courses. We had courses on driver's license, where there are buses or trucks, and women went for it too. And the men? Men are afraid of the new one, they are afraid of retraining (...) Also, it is often the case that the responsibility for the bome and the family is often thrown on the woman (Social worker, 41 years old, small town).

The strategies to address financial hardship undertaken by beneficiary poor families vary according to the type of family, the problems they are experiencing and the resources at their disposal. An important element of actions is also the motivation to undertake them and the recognition of using social assistance as a temporary or permanent element in family life: There are different clients. These are those people who have been simply forced by a difficult situation to apply for social assistance. Such a families in a truly difficult financial situation had suddenly found itself in it and are doing everything to escape from it. There are also families who benefit from the so called multi-generational social assistance inheritance. This is a more difficult situation because it is simply a babit.

The habit of using social assistance that parents pass on to their children from generation to generation (Social worker, 59, big city).

Attention should be paid to the relationship between the type of strategy undertaken and the socioeconomic status and emotional state of the poor. The higher the social status (education, occupation, background) and economic status of the poor (the lower the depth of poverty), the more effective and active strategies are. The deeper the poverty and the low level of human capital (education, skills, health), the more often passive strategies are involved (Caplan, Schooler, 2007).

\subsection{Barriers to minimizing poverty among clients and families benefiting from social assistance in the opinion of the respondents}

The main pillar of many Polish and European programmes for preventing and fighting poverty is employment. In modern society, work is an important social institution situating people in many other dimensions of social structure. It is not only a method of gaining financial resources, but one of the basic ways of developing human 
personality. According to Ralph Dahrendorf (1993), work is a ticket to the world of resources, i.e. to full civil rights. The lack of earning opportunities restricts an individual's access to other spheres of social life such as the health care, education, culture and consumption system. Over the past decades, the policy of counteracting poverty in European countries has been based on the idea that the main way out of poverty for families (adults and children) is to equalize the development opportunities of future adults, support for parents and their integration into the labour market (Frazer, Marlier, 2014).

The economic statute of citizens is nowadays determined mainly by three interpenetrating spheres: family, market and state (Esping-Andersen, 2010). In each of these segments of the space of functioning of an individual and families, there is a more or less explicit concept of the division of social roles by gender and the resulting limitations or opportunities in shaping the income of women and men and minimizing poverty (Firlit-Fesnak, 2015). Differences in parental, family and professional roles shape opportunities to minimize poverty and empower social assistance clients and their families. Social workers in the quantitative and qualitative research were asked to identify the main barriers to the empowerment of families and persons benefiting from institutional support.

Table 1. The main barriers occurring in the case of attempts to empower beneficiaries from social assistance in the social workers' opinion in Poland

\begin{tabular}{|c|c|c|}
\hline & Social assistance clients (Men) & Social assistance clients (Women) \\
\hline 1. & $\begin{array}{l}\text { Getting used to living from social assistance } \\
(69 \%)\end{array}$ & $\begin{array}{l}\text { Care of dependent persons - children, the } \\
\text { sick }(58 \%)\end{array}$ \\
\hline 2. & No motivation to change $(49 \%)$ & $\begin{array}{l}\text { Getting used to living from social assistance } \\
(45 \%)\end{array}$ \\
\hline 3. & $\begin{array}{l}\text { High level of unemployment in the } \\
\text { region/lack of job offers }(24 \%)\end{array}$ & Low education, lack of qualifications $(33 \%)$ \\
\hline 4. & Claimant client attitude $(20 \%)$ & $\begin{array}{l}\text { Too much burden of household and family } \\
\text { chores }(31 \%)\end{array}$ \\
\hline 5. & Disease/disability (14\%) & No motivation to change $(24 \%)$ \\
\hline 6. & $\begin{array}{l}\text { Too much burden of household and family } \\
\text { chores }(1 \%)\end{array}$ & Learned helplessness $(22 \%)$ \\
\hline 7. & $\begin{array}{l}\text { Care of dependent persons - children, the sick } \\
(1 \%)\end{array}$ & $\begin{array}{l}\text { High level of unemployment in the } \\
\text { region/lack of job offers }(21 \%)\end{array}$ \\
\hline 8. & $\begin{array}{l}\text { Lack of adequate social infrastructure e.g. } \\
\text { kindergartens, crèches }(0,7 \%)\end{array}$ & $\begin{array}{l}\text { Alcoholism (or other addiction) of the } \\
\text { spouse/partner }(21 \%)\end{array}$ \\
\hline 9. & Others $(0,5 \%)$ & $\begin{array}{l}\text { Lack of adequate social infrastructure e.g. } \\
\text { kindergartens, crèches }(18 \%)\end{array}$ \\
\hline 10. & --- & $\begin{array}{l}\text { Being out of work for too long/chronic } \\
\text { unemployment }(18 \%)\end{array}$ \\
\hline
\end{tabular}

Source: own research. The percentages do not add up to 100, because social workers could choose more than one answer. $N=500$.

The quantitative data obtained during the survey of social workers show that the main barriers to minimizing poverty for individuals and families in the case of social assistance clients are related to their attitude to life. Social workers pointed out that men are 
characterized by a passive attitude to the problem related to getting used to life from social assistance and a lack of motivation to change their own and family life situation: Some clients seem to me to have simply learned to use this help in such a way that the main barrier is themselves. They are so comfortable with it. They have a certain source of funding from us, they come to apply on time, they get help and I think that's enough for them. And this is the barrier, their approach to life. Other barriers are certainly the labour market, that there is simply no job in our region. That's definitely a barrier. Sometimes the age of these people (Social worker, 36 years old, small town). The social workers pointed out that it is more difficult to motivate men than women for actions aimed at changing their family situation. This motivation is greater in women, the greater the threat to the family and its stability. Social workers stressed that often mothers are the most motivated if they notice that change can have a positive impact on children or prevent the separation of the family: It is easier to motivate women if we refer to the family, to children, we show advantages for children, for the family. A man is more already hardened in his attitude. They often do not have such internal motivation, it is more difficult to motivate them. Women find it easier, because they feel responsible for someone, for children. This is important for them, especially when it comes to these caring and educational problems. If they know that they can lose their children, what the consequences may be, they will do something. And the men when they take the children away, they'll say 'I will be better off there". That's their attitude a bit, they don't care so much about it (Social worker, 35 years old, rural area).

A passive approach to poverty, according to social workers, is also characterized by a significant proportion of social assistance clients. The respondents pointed out that some of the beneficiaries manifested the so-called "learnt helplessness syndrome". Helplessness is defined as a category determined by specific deficits of will, mental efficiency, means of positive action, as well as the limitation of material means needed for action. It causes disorders of self-esteem, lack of self-confidence and perception of one's own person as an addicted, dominated and subordinate individual among others (social marginalization) and the feeling of dominating one's own life and acting by fate (external feeling of control) (Pilch, 2005). The syndrome of learned helplessness is characterized by the following elements: motivational deficit (decrease in the tendency to initiate action, apathy), emotional deficit (mood worsening, depressive mood), cognitive deficit, association deficit (decrease in the ability to deal with problems independently in situations previously controlled, causing difficulties in perceiving the relationship between one's own action and its consequences) (Wysocka, 2008). As one of the social workers indicates: They often don't know how to live differently and are afraid of taking any action. Even if we are active here and the woman goes through a vocational course and there is a chance to work, these women multiply their problems, because they have children, because the child will come home from school and won't have lunch, because she has so many duties at home, she won't manage otherwise (...) Such a fear of something new also that she won't manage. If they just sit at home and are dependent on a man or on state aid, it seems to them that they simply won't work in anything else and won't be able to cope. And also their low self-esteem, low belief in success (Social worker, 43 years old, rural area).

According to the social workers, the greatest barrier for women to become independent from social assistance is their much greater involvement in family and caring matters. The economic dependence of women on their partners/husbands is linked to the culturally conditioned division of labour by gender, assigning men to the public (professional) sphere, while women are burdened with domestic and caring work. In 
addition, unpaid domestic and care work for women is generally not reflected in social security systems (Firlit-Fesnak, 2015). The respondents stressed that in families benefiting from social assistance almost exclusively women are responsible for the care of minors, children and other dependents, e.g. the chronically ill, disabled, elderly. Women in these families also perform most of the household duties. The scenario of women emerging from poverty through economic activity is therefore closely related to the availability of public care services for children and dependents, which is strongly differentiated in individual voivodeships or territorial units (e.g. large cities vs. peripheral villages): It is more difficult for women to return to the labour market after the period of bringing up a child, after maternity and parental leave. It is more difficult for them to find a job after such a period of exclusion from employment (...) Besides, it is more difficult for women to take any action, especially if they have small children. It is also difficult to show her the way if she does not have even an institutional background in terms of childcare (Social worker, 39 years old, big city). Social workers from rural areas stressed that access to kindergartens is limited. These facilities are often located at considerable distances or are difficult to reach. On the other hand, employees from large and large cities indicate that due to a small number of public kindergartens and a large number of applicants, access to kindergartens for children of unemployed mothers is very limited. Therefore, women cannot effectively look for a job or, even when they find a job, are not able to provide childcare due to the lack of places in nurseries, kindergartens or other institutions providing care for dependents. Often social workers even write letters of support in order to admit their clients' children to nurseries or crèches. In addition, social workers stressed that employers are reluctant to hire mothers with young children because of the general opinion that they are less available and more likely to be absent from the workplace. It is more difficult for women to return to the labour market after the period of raising a child, after maternity and parental leaves. An important element here is also the limited (or even complete lack of) professional experience of women, which is connected with a break in work for the time of childcare. This situation, linked to the low education of social assistance clients and the low number of job offers on the local market, causes difficulties in finding stable employment which could help to overcome the difficult financial situation of the family.

\section{Conclusions}

In a situation of limited income, which does not allow to meet the basic needs of the family, its representative may go to the social welfare center and apply for various types of social assistance to overcome difficult life situations. The essence of this support is, on the one hand, to enable social functioning in conditions corresponding to human dignity and, on the other hand, to lead to a situation in which the family will no longer have to use this assistance. However, very often families that benefit from this support undertake a number of actions themselves, which are aimed at increasing their income or at minimizing expenses. The social workers surveyed stressed that the majority of families benefiting from this support undertake a number of actions to improve their material situation and to solve the problems they experience. According to the social workers, strategies vary according to the gender of those taking them on, family resources and the type of problems they face. Men generally take active measures to earn 
income from work (legal or not), due to the lesser burden of household chores and childcare. Women, on the other hand, focus on obtaining institutional support for the family in the form of financial benefits, assistance in solving upbringing problems and passive actions aimed at reducing the spending of resources (buying second-hand, cheaper things, etc.).

The vast majority of families benefiting from social assistance support face financial problems due to unemployment of adult family members. Activities aimed at empowering social assistance clients are therefore often connected with professional activation. Social workers pointed out that the problem of unemployment affecting social assistance clients is significant. They stressed that there are very few job offers in many smaller towns and cities and that there is a lot of competition among those ready to take up a job. Moreover, social assistance clients are generally people with low qualifications and education. However, the problem of unemployment is much more complex among persons and families benefiting from social welfare centers. Men often, despite greater opportunities (employers' preferences, lower burden of childcare and household duties) show less commitment to actions aimed at separating the family from social assistance support. The barrier to minimizing family poverty through employment for women is their burden of domestic and family responsibilities and the lack of adequate social infrastructure enabling them to combine activities undertaken in the private and professional spheres. A problem is also the rigid and traditional perception of gender roles, which limits women's professional activation.

\section{References}

Babbie, E. (2008). Podstawy badań społecznych. Warszawa: Wydawnictwo Naukowe PWN.

Caplan, L. J., Schooler, C. (2007). Socioeconomic Status and Financial Coping Strategies: The Mediating Role of Preceived Control. Social Psychology Quarterly, 70(1), 43-58.

Dahrendorf, R. (1993). Nowoczesny konfliket społeczny. Esej o polityce wolności. Warszawa: Czytelnik.

Esping-Andersen, G. (2010). Spoteczne podstawy gospodarki postindustrialnej, Warszawa: Wydawnictwo WSP.

Firlit-Fesnak, G. (2015). Bieda i ptéc. Strefy podzialu kreujace ubóstwo kobiet w krajach Unii Europejskiej. Warszawa: Oficyna Wydawnicza ASPRA-JR.

Frankfort-Nachmias, C., Nachmias, D. (2001). Metody badawcze w naukach społecænych. Poznań: Zysk i S-ka Wydawnictwo s.c.

Frazer, H., Marlier, E. (2014). Investing in Children: Breaking the Cycle of Disadvantage, Luxembourg: Publications Office of the European Union.

Golinowska, S., Broda-Wysocki, P. (2005). Kategorie ubóstwa i wykluczenia społecznego. Przegląd pojecć. In Golinowska S., Tarkowska E., Topińska I. (eds.), Ubóstwo i nykluczenie społečne. Badania. Metody. Wyniki. Warszawa: Instytut Pracy i Spraw Socjalnych.

GUS. (2019a). Zasieg ubóstwa ekonomicznego w Polsce w 2018 roku. Warszawa: DBSiWZ.

GUS. (2019b). Beneficjenci środowiskowej pomocy społecznej w 2018 roku. Warszawa-Karkow: GUS.

Janocha, W., Olesińska, A. (2019). Feminizacja ubóstwa i strategie radzenia sobie z biedą na przykładzie mieszkanek Lublina. Roczniki Teologiczne, 1, 47-62.

Kostera, M., Kociatkiewicz, J. (2014). Zaangażowane badania jakościowe. Problemy Zarzadzania, 12(2), 9-17.

Kvale, S. (2004). InterViews. Wprowadzenie do jakościowego nywriadu badawczego. Białystok: Trans Humana.

Lister, R. (2007). Bieda. Warszawa: Wydawnictwo Sic!

MRPiPS (2019). www.gov.pl/web/rodzina/statystyka-za-rok-2018 Accessed 15/06/2020.

Pankowska, D. (2005). Wychowanie a role ptciowe. Gdańsk: Gdańskie Wydawnictwo Psychologiczne.

Pilch, R. (2005). Encyklopedia pedagogiczna XXI wieku, Warszawa: Wydawnictwo Akademickie Żak.

Racodi, C. (2002). A livelihoods Approach; A conceptual issues and definitions. In Racodi C., Lloyd-Jones T. (eds.). Urban Livelihoods: A People-Centered Approach to Reducing Poverty. London: Earthscan. 
Sassen, S. (2000). Women's burden: Counter-geographies of globalization and feminization of survival. Journal of International Affairs, 1, 503-524.

Szarfenberg, R. (2009). Ubóstwo, marginalność i wykluczenie społeczne. In Firlit-Fesnak G. (eds.). Politylka spoteczna. Warszawa: Wydawnictwo Naukowe PWN.

Sztabiński, P., Sawiński, Z., Sztabiński, F. (2005). Fieldwork, jest sætukq. Warszwa: Wyd. IFiS PAN.

Tarkowska, E. (2004). Dziecko w biednej rodzinie. Polityka Społeczna, 9, 9-13.

Tarkowska, E. (2015). O strategiach radzenia sobie z biedą. In: Mikołajczyk M. (ed.). Ubóstwo, bezrobocie, bezdomność. Działania profilaktyczne, pomocowe. Warszawa: Wyd. APS.

Titkow, A. (1996). Społeczna i kulturowa tożsamość kobiet. Ask: Research and Methods, 2 (4), 73-77.

Titkow, A., Duch-Krzystoszek, D., Budrowska, B. (2004). Nieodplatna praca kobiet - mity, realia, perspektyny. Warszawa: Wydawnictwo IFiS PAN.

Tyszka, Z. (2002). Rodzina we współczesnym świecie. Poznań: Wydawnictwo Naukowe UAM.

Ustawa o pomocy społecznej z dnia 12 marca 2004 roku, Dz.U.2004.64.593

Walczewska, S. (1999). Damy, rycerze i feministki. Kobiecy dyskurs emancypacyjny w Polsce, Krakow: eFKa.

Wysocka, E. (2008). Psychospoteczne korelaty berradności spotecznej, Polityka Społeczna, nr 4, 1-9.

Zalewski, D. (2005). Opieka i pomoc spoleczna. Dynamika instytucji, Warszawa: Wydaw. UW.

Zasada-Chorab, A. (2012). Ramy prawne i organizacyjne systemu pomocy społecznej w Polsce. In Grewiński M., Zasada-Chorab A. (eds.), System pomocy społecznej w Polsce. Toruń: ROPS 